\title{
Pterygium in Indonesia: prevalence, severity and risk factors
}

\section{G Gazzard, S-M Saw, M Farook, D Koh, D Widjaja, S-E Chia, C-Y Hong, D T H Tan}

Series editors: W V Good and S Ruit

See end of article for authors' affiliations .....................

Correspondence to: Mr Gus Gazzard Department of Wound Healing, Institute of Ophthalmology, Bath Street, London ECIV 9EL, UK; gusgazzard@ hotmail.com

Accepted for publication 16 July 2002

\begin{abstract}
Aim: To determine prevalence rates, severity, and risk factors for pterygium in adults in provincial Indonesia and to validate a clinical grading scheme in a population based setting.

Methods: A population based prevalence survey of 1210 adults aged 21 years and above was conducted in five rural villages and one provincial town in Riau province, Sumatra, Indonesia, an area near to the equator. A one stage household cluster sampling procedure was employed: 100 households were randomly selected from each village or town. Pterygia were graded for severity (T1 to T3, by visibility of episcleral vessels) and the basal and apical extent measured by an ophthalmologist (GG) with a hand held slit lamp. Refraction was measured by hand held autorefractor (Retinomax). Face to face household interviews assessed outdoor activity, occupation, and smoking. The participation rate was $96.7 \%$.

Results: The mean age was 36.6 years (SD 13.1), 612 were male. The age adjusted prevalence rate of any pterygium was $10.0 \%$ (95\% confidence intervals (CI) 8.2 to 11.7$)$ and of bilateral pterygia was $4.1 \%(95 \% \mathrm{Cl} 2.9$ to 5.3$)$. There was a significant dose-response relation with age $(2.9 \%(95 \% \mathrm{Cl} 0.4$ to 5.8$)$ for $21-29$ years versus $17.3 \%(95 \% \mathrm{Cl} 10.4$ to 24.2$) 50$ years and above; $p$ for trend $<0.001)$ and occupations with more time outdoors ( $\mathrm{p}$ for trend $=0.02$ ). This was true for both sexes, all grades of lesion (T1 to T3), and bilateral disease. A multivariate logistic regression model showed pterygium was independently related to increasing age and outdoor activity 10 years earlier. The mean basal diameter $=3.3 \mathrm{~mm}$ (SD 1.51, range 0.1-9.5) and extent from limbus = $1.4 \mathrm{~mm}$ (SD 1.18, range 0.18.0). Higher grade pterygia were larger for basal and apical extent ( $p$ for trend $<0.001$ ). The presence of pterygium was associated with astigmatism (defined as cylinder at least -0.5 dioptres (D); $p$ $<0.001$ ). This association increased with increasing grade of lesion ( $p$ for trend $<0.001$ ). Median cylinder for those with pterygium $(-0.50 \mathrm{D})$ was greater than for those without $(-0.25 \mathrm{D}),(\mathrm{p}<0.001)$, and increased with higher grade of lesion ( $p$ for trend $<0.001$ ). For eyes with pterygia, magnitude of astigmatism was associated with greatest extent from the limbus, $(p=0.03)$, but not basal width $(p=0.99)$. Conclusions: There is a high prevalence rate of pterygia in provincial Sumatra. The independent increase with age and past outdoor activity (a surrogate for sun exposure) is consistent with previous findings. Clinical grading of pterygium morphology by the opacity of the lesion was a useful additional marker of severity.
\end{abstract}

$\mathrm{P}$ terygium is a disfiguring and potentially blinding disease that in the advanced stages can require complex surgery for full visual rehabilitation. ${ }^{1}$ Insights into risk factors, causes, and the distribution of the disease may be useful in guiding appropriate strategies for preventive measures. ${ }^{2}$ The prevalence rates of pterygium obtained for a number of populations vary widely, ${ }^{3-7}$ from $1.2 \%$ in urban, temperate white people $^{8}$ to $23.4 \%$ in the black population of tropical Barbados. ${ }^{2}$ These study populations differ in race, latitude, and sun exposure, but generally prevalence rates in the tropics are higher than at temperate latitudes. Theories of the pathogenesis of pterygium have implicated ultraviolet light exposure as a major causative factor. Evidence for sunlight exposure as one of the prime aetiological agents derives both from case-control studies $^{9}$ and prevalence surveys. ${ }^{4810-13}$

As with theories of pathogenesis, techniques of treatment for pterygia have advanced in recent years. Alongside recognition of mechanisms of disordered cell growth ${ }^{14-19}$ has been the development of techniques for conjunctival ${ }^{2021}$ and amniotic membrane ${ }^{1}$ transplantation to reduce recurrence after surgery. It has been further shown, in a randomised control trial comparing bare sclera excision with conjunctival autografting, that simple clinical grading of pterygium morphology can usefully predict the likelihood of recurrence. ${ }^{20}$

We report the findings of a prevalence study from equatorial Indonesia and the application of this same morphological grading scheme to this population based sample. Ours is the first study, to our knowledge, to examine the Malay/ Indonesian racial group.

\section{METHODS}

A population based prevalence survey in five rural villages and one provincial town of Riau province, Sumatra, Indonesia, was conducted from April to June 2001 as part of a large general village health survey. The region is tropical with secondary forests, near the Kampar River, one degree north of the equator, and the nearest large city is the capital of the Riau province, Pekan Baru. A random sample of all household members living in five villages (Kuala Terusan Baru, Pelalawan, Delik, SP7, and Segati) and the nearby provincial town, Kerinci was assessed. Villages were variously situated in forest (Segati), near logging roads (Kuala Terusan Baru, Delik), alongside the Kampar River (Pelalawan), and close to a paper and pulp mill (SP7). All houses in each village were individually mapped and assigned a number by an enumeration team. A one stage cluster sampling procedure was conducted whereby 100 households were randomly selected from a sampling frame of the total number of households in each village (as there were only 60 households in Delik all 60 were assessed). Membership of a household was defined as 
Table 1 Age-sex specific prevalence rates of pterygia in provincial south Sumatra, Indonesia

\begin{tabular}{|c|c|c|c|c|c|c|}
\hline \multirow[b]{3}{*}{ All ages } & \multicolumn{6}{|c|}{ Prevalence rate, any pterygium $(95 \% \mathrm{Cl})$} \\
\hline & \multicolumn{2}{|c|}{ Total $(n=1210)$} & \multicolumn{2}{|c|}{$\operatorname{Men}(n=612)$} & \multicolumn{2}{|c|}{ Women $(n=598)$} \\
\hline & (n) & & & & & \\
\hline Crude rate & 1210 & $9.3(7.3,11.2)$ & 612 & $10.0(7.4,12.5)$ & 598 & $8.5(5.5,11.6)$ \\
\hline Age adjusted rate* & & $10.0(8.2,11.7)$ & & $10.4(7.9,12.9)$ & & $9.5(7.0,12.0)$ \\
\hline \multicolumn{7}{|l|}{ Age (years) } \\
\hline $21-29$ & 414 & $2.9(0.4,5.8)$ & 185 & $3.8(0.0,7.8)$ & 229 & $2.2(0.02,4.3)$ \\
\hline $30-39$ & 393 & $8.1(3.0,13.3)$ & 212 & $8.5(3.0,14.0)$ & 181 & $7.7(16.8,13.8)$ \\
\hline $40-49$ & 201 & $16.4(9.5,23.3)$ & 104 & $14.4(3.5,25.4)$ & 97 & $18.6(13.6,23.5)$ \\
\hline 50-and above & 202 & $17.3(10.4,24.2)$ & 111 & $18.9(10.6,27.2)$ & 91 & $15.4(9.5,21.2)$ \\
\hline $\mathrm{p}$ (trend) & & $<0.001$ & & $<0.001$ & & $<0.001$ \\
\hline \multicolumn{7}{|c|}{ Income (rupiah† per month) } \\
\hline$<500000$ & 584 & $10.1(7.0,13.3)$ & 294 & $11.2(7.9,14.6)$ & 290 & $9.0(5.4,12.5)$ \\
\hline $500000-1000000$ & 430 & $9.8(4.6,14.9)$ & 217 & $10.1(6.7,16.5)$ & 213 & $9.4(3.4,15.4)$ \\
\hline 1000000 or more & 196 & $5.6(2.4,8.9)$ & 101 & $5.9(1.5,11.7)$ & 95 & $5.3(1.6,10.4)$ \\
\hline $\mathrm{p}$ (trend) & & 0.1 & & 0.16 & & 0.38 \\
\hline \multicolumn{7}{|l|}{ Smoking } \\
\hline Never smoked & 625 & $9.4(6.8,12.1)$ & 105 & $12.4(8.6,16.1)$ & 520 & $8.8(5.4,12.3)$ \\
\hline Ever smoked & 585 & $9.1(5.9,12.2)$ & 507 & $9.5(6.0,12.9)$ & 78 & $6.4(2.1,10.7)$ \\
\hline$p$ value & & 0.82 & & 0.37 & & 0.48 \\
\hline \multicolumn{7}{|l|}{ Occupation $\ddagger$} \\
\hline Level 0 & 594 & $7.5(3.7,11.4)$ & 149 & $8.7(3.3,14.1)$ & 445 & $7.2(3.4,11.0)$ \\
\hline Level 1 & 110 & $9.1(2.2,16.0)$ & 66 & $12.2(2.1,22.2)$ & 44 & $4.5(1.0,8.1)$ \\
\hline Level 2 & 74 & $9.4(0.0,21.6)$ & 28 & $10.7(0.0,26.3)$ & 46 & $8.7(0.0,21.8)$ \\
\hline Level 3 & 63 & $6.3(0.3,12.4)$ & 54 & $5.6(0.0,12.6)$ & 9 & $11.1(2.6,19.6)$ \\
\hline Level 4 & 369 & $12.4(6.9,18.0)$ & 315 & $10.8(5.4,16.1)$ & 54 & $22.2(12.5,32.0)$ \\
\hline $\mathrm{p}$ (trend) & & 0.02 & & 0.7 & & 0.001 \\
\hline \multicolumn{7}{|l|}{ Outdoor activity } \\
\hline \multicolumn{7}{|l|}{5 years ago } \\
\hline$>5$ hours/day & 568 & $11.1(8.3,13.9)$ & 208 & $11.2(7.7,14.6)$ & 434 & $11.0(5.8,16.2)$ \\
\hline$\leqslant 5$ hours/day & 642 & $7.6(5.4,9.9)$ & 404 & $7.7(4.0,11.4)$ & 164 & $7.6(4.8,10.4)$ \\
\hline$p$ value & & 0.2 & & 0.18 & & 0.19 \\
\hline \multicolumn{7}{|l|}{10 years ago } \\
\hline$>5$ hours/day & 575 & $12.3(9.0,15.6)$ & 228 & $13.0(9.7,16.7)$ & 407 & $11.0(4.4,17.6)$ \\
\hline$\leqslant 5$ hours/day & 635 & $6.5(3.6,9.4)$ & 384 & $4.8(0.6,9.0)$ & 191 & $7.4(4.5,10.2)$ \\
\hline $\mathrm{p}$ value & & 0.001 & & 0.002 & & 0.14 \\
\hline
\end{tabular}

the habitual occupation of that dwelling with a presence in the house for at least 2 of the preceding 4 weeks.

Among the randomly selected 1251 adult villagers 21 years and above, examinations were performed on 1210, an initial participation rate of $96.7 \%$. There were 216 subjects recruited from Kerinci, 231 subjects from Kuala Terusan Baru, 229 from Pelalawan, 120 from Delik, 233 from SP7 and 181 from Segati. Of these, 297 were described as possible positives in the initial screening survey and 248 were re-examined (a secondary participation rate of $83.5 \%$ ). The unexamined subjects were considered as negative cases for the purpose of this analysis. Nonparticipants included non-contactables and refusals. Noncontactables were defined as individuals who were not contactable on three separate occasions and refusals defined as individuals who declined to participate in the study. The median age of the participants $(33.0$ years, $n=1210)$ and non-participants ( 31.0 years, $\mathrm{n}=41$ ) was not different $(\mathrm{p}=$ 0.64 , rank sum test).

\section{Sample size estimation}

A sample size of 1030 was needed for a two sided hypothesis to estimate the prevalence of pterygium of $10 \%$ and an allowable difference of 3\%, if the power was 0.9 and type I error, $\alpha$ was 0.05 . A non-participation rate of $10 \%$ was factored in the estimation.

Training of team members and a pilot study of 16 subjects in SP7 were conducted in April 2001, 2 weeks before the survey proper. Before the examinations, meetings were held with the village leaders to explain the purpose of the study and obtain cooperation from the community. Informed verbal consent was obtained from the subjects and all subjects were treated in accordance with the tenets of the Declaration of Helsinki. Approval for the study was obtained from the ethics committee, Singapore Eye Research Institute.

\section{Eye examinations}

A trained interviewer visited each identified house and examined both eyes of all household members. Training of interviewers in the recognition of pterygium was conducted by a single qualified ophthalmologist from singapore (GG) using a standard set of photographs. Examination was performed with an oblique torchlight from the inferotemporal approach. For the purposes of the initial detection survey positive cases were defined as those with any lesion extending up to or crossing the nasal or temporal limbus. Each interviewer was issued with a reference set of standard photographs. To ensure the detection of subtle lesions, avoid false negatives and to minimise diagnostic errors, all interviewers were instructed to label as "positive" all pingueculae and any lesion about which they were at all uncertain. Ophthalmologists, public health doctors, and an optometrist made quality checks of each interviewer's competence in the detection of pterygia during the pilot study and again on several occasions during the study. 
Table 2 Age and sex specific prevalence rates of the different grades of pterygia $(n=1210)$

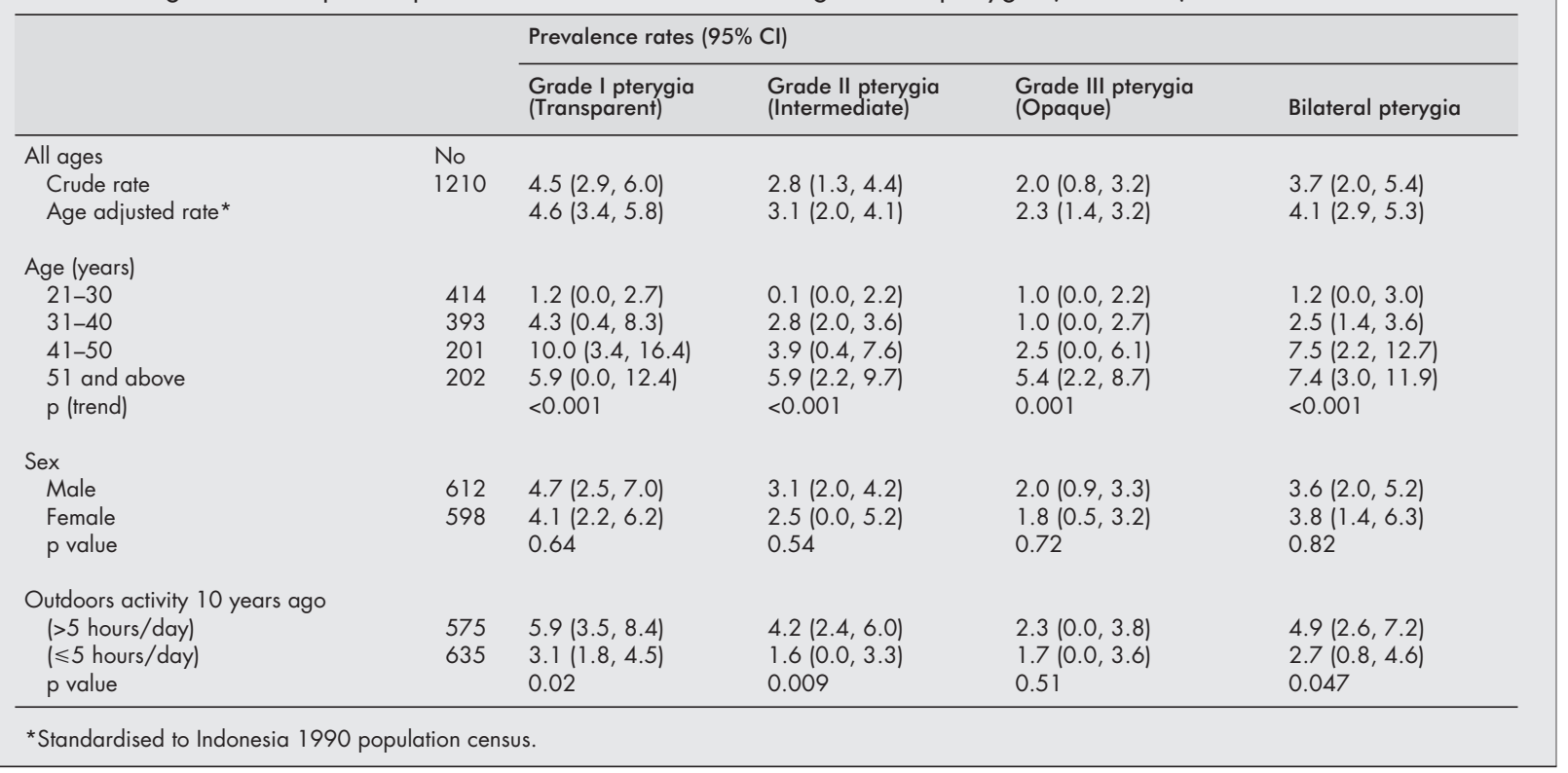

Corrected and uncorrected distance visual acuity was measured in good lighting conditions (outside the village hut) using tumbling "E" $\log$ MAR charts for each eye separately following a standard protocol (Ferris). Autorefraction measurements in the right and left eye were performed using one of two hand held autorefractors, the Retinomax K-plus (Nikon, Tokyo, Japan) and the average of eight refractive error readings were taken without cycloplegia. ${ }^{22}$

\section{Pterygia grading}

Follow up examination for corroboration of the diagnosis and grading was conducted by a single trained ophthalmologist (GG) using a portable slit lamp (Kowa Co Ltd, Japan) in the villages on all subjects identified. Pterygia were defined as a radially oriented fibrovascular lesion crossing the nasal or temporal limbus. Grading was based on the visibility of the underlying episcleral blood vessels. This has been previously described and validated as a marker of severity. ${ }^{20} \mathrm{Tl}$ ("atrophic") is defined as episcleral vessels clearly visible, T2 ("intermediate") as vessels partially visible, and T3 ("fleshy, opaque") as vessels wholly obscured. Size was measured with calipers as the chord length of the corneal limbus involved and the greatest distance from the limbus to the apex of the lesion.

\section{Demographic and lifestyle data}

Data on demographic and lifestyle factors were collected by means of in-person household interviews by trained interviewers using a standard questionnaire. This was translated into Bahasa Indonesia and back translated into English to ensure the accuracy of translation. The questionnaire was pilot tested in 29 adults in two of the villages (SP7 and Kerinci). Individual questions were revised and rephrased. Interviewers were Indonesian nurses and volunteers all fluent in Bahasa Indonesia. The villagers were asked about the total family income, the number of hours spent outdoors in the sun per day, currently and 5 and 10 years ago, and smoking status. A detailed occupational history was taken. Occupations were grouped into five levels by an occupational health physician with experience of rural Indonesia, based on the average daytime sun exposure experienced: level $0=$ factory worker, student, homemaker, unemployed government officer, teacher, nurse; level $\mathrm{l}=$ entrepreneur, private employer, level $2=$ animal breeder, daily worker, rubber tapper, goods seller; level $3=$ driver, level 4 = fisherman, farmer, wood collector, construc- tion worker, labourer, plantation worker ( 0 is indoors, $1-4$ are outdoors, with increasing time spent outdoors, 0 through 4 ).

\section{Definitions and data analysis}

A subject was defined as "positive" for pterygium if at least one pterygium lesion was confirmed in either eye by the examining ophthalmologist. The prevalence rates and 95\% CI of pterygia for subjects with different characteristics were calculated, allowing for clustering by household and village. Age adjusted rates were derived using 1990 Indonesian national census data. The crude and multivariate odds ratios with 95\% CI denoting the associations between the various lifestyle variables and pterygia were calculated. Adjusted odds ratios were obtained using multiple logistic regression models, with adjustment for clustering. All statistical analyses were performed using the commercially available software STATA version 7.0 (STATAcorp).

\section{RESULTS}

The mean age was 36.6 years (SD 13.1). There were 612 males and 598 females. The proportion of villagers who owned a radio was $56.6 \%, 59.4 \%$ owned a television set, and electricity was available in $82.3 \%$ of the dwellings. Eighty six per cent were married, $8.4 \%$ single, and $5.6 \%$ were widowed or divorced.

The overall age adjusted prevalence rate of any pterygia in adults over 21 was $10.0 \%$ (95\% CI 8.2 to 11.7 ). The age-sex specific prevalence rates of pterygia are shown in Table 1 . The rates for all adults over 40 years were $16.8 \%$ (95\% CI 10.8 to 22.8 ) overall, $16.1 \%$ (95\% CI 8.3 to 24.0 ) for males and $17.6 \%$ (95\% CI 12.8 to 2.4 ) for females.

The rates in subjects over 51 years were six times that of the $21-30$ year olds $(17.3 \% \vee 2.9 \%)$. The dose-response relation with age was similar for males and females. The prevalence in the greatest income group was half that of the lowest $(5.65 \%$ $v 10.1 \%)$ though this was not significant $(\mathrm{p}=0.095)$. There was no significant difference in the rates of pterygia by side (right $6.4 \%$ (95\% CI 5.1 to 7.8 ); left $6.6 \%$ (95\% CI: 4.5 to 8.8 ), $\mathrm{p}=0.8$ ) or sex (males $10.0 \%$ (95\% CI 7.4 to 12.5 ); females $8.5 \%$ (95\% CI: 5.5 to 11.6 ), $\mathrm{p}=0.37$ ). A history of smoking was not significantly related to pterygium in the univariate analysis (no smoking history $9.4 \%$ (95\% CI 6.8 to 12.2 ); any smoking history 9.1 (95\% CI: 5.8 to 12.2 ), $\mathrm{p}=0.82$ ). There was no difference in the location (nasal $v$ temporal), grade, extent or 
Table 3 Characteristics of all pterygia lesions $(n=163)$

\begin{tabular}{|c|c|c|c|c|c|}
\hline & $\begin{array}{l}\text { All pterygia } \\
(n=163)\end{array}$ & $\begin{array}{l}\text { Grade I pterygia } \\
\text { (transparent) } \\
(\mathrm{n}=89)\end{array}$ & $\begin{array}{l}\text { Grade II pterygia } \\
\text { (intermediate) } \\
(n=42)\end{array}$ & $\begin{array}{l}\text { Grade III } \\
\text { pterygia } \\
\text { (opaque) } \\
(n=32)\end{array}$ & $\mathrm{p}$ Value \\
\hline \multicolumn{6}{|c|}{ Width of base (mm) } \\
\hline $\begin{array}{l}\text { Mean (SD) } \\
\text { (range) }\end{array}$ & $\begin{array}{l}3.3(1.51) \\
(0.1-9.5)\end{array}$ & $\begin{array}{l}2.6(1.29) \\
(0.1-6.0)\end{array}$ & $\begin{array}{l}3.7(1.8) \\
(1.0-6.0)\end{array}$ & $\begin{array}{l}4.5(1.5) \\
(1.5-9.5)\end{array}$ & $\begin{array}{l}<0.001 \\
\text { (for trend) }\end{array}$ \\
\hline \multicolumn{6}{|c|}{ Extent from limbus (mm) } \\
\hline \multirow[t]{2}{*}{$\begin{array}{l}\text { Mean (SD) } \\
\text { (range) }\end{array}$} & $\begin{array}{l}1.4(1.18) \\
(0.1-8.0)\end{array}$ & $\begin{array}{l}1.0(0.71) \\
(0.1-3.0)\end{array}$ & $\begin{array}{l}1.6(0.9) \\
(0.5-4.0)\end{array}$ & $\begin{array}{l}2.3(1.9) \\
(0.5-8.0)\end{array}$ & $\begin{array}{l}<0.001 \text { ) } \\
\text { (for trend) }\end{array}$ \\
\hline & No $(\%)$ & & & & \\
\hline \multicolumn{6}{|l|}{ Location } \\
\hline Nasal & 152 (93) & $80(90)$ & $42(100)$ & $30(94)$ & 0.1 \\
\hline $\begin{array}{c}\text { Temporal } \\
\text { Affected eye }\end{array}$ & $11(7)$ & $9(10)$ & \multicolumn{2}{|c|}{ Affected eye } & \\
\hline Right & $82(50)$ & $47(53)$ & $19(45)$ & $16(50)$ & 0.72 \\
\hline Left & $81(50)$ & 42 (47) & $23(55)$ & $16(50)$ & \\
\hline
\end{tabular}

width of pterygia between right and left eyes. As expected nasal pterygia $(9.3 \%$, CI: 7.2 to 11.3$)$ were far more common than temporal (0.91\%, CI: 0.6 to 1.2$)$.

A history of more than 5 hours per day of outdoor activity 10 years earlier was associated with almost twice the rate of those without such a history ( $12.3 \% v 6.5 \%$, Table 1$)$, whereas a history of more than 5 hours per day of outdoor activity 5 years earlier was not significantly related $(7.7 \% v 11.1 \%$, $\mathrm{p}=0.2$ ). The mean time spent outdoors per day 10 years earlier was higher for those with pterygia than those without $(6.0 \mathrm{v}$ 5.4 hours/day, $p=0.017$ ), but not significantly different for current exposure or that 5 years before $(4.6 \vee 4.2, \mathrm{p}=0.59$, and $5.8 v 5.4, \mathrm{p}=0.14$, respectively). An occupation involving any outdoor activity was associated with more pterygia than an occupation with none $(7.6 \%, 95 \%$ CI 3.7 to 11.4$)$ for indoor occupations $v 10.9 \%$ (95\% CI 6.9 to 14.8 ) for outdoor, $\mathrm{p}=$ $0.049 ; \mathrm{OR}=1.5(95 \% \mathrm{CI} 1.5$ to 2.2$)$. The associations of increasing time spent outside and higher prevalence rates were significant for grades 1 and 2 and the occurrence of bilateral disease, but not for grade 3 pterygia for which the numbers were smaller (Table 2). Habitually wearing a hat outdoors ( $16.9 \%$ of individuals), conferred no significant protection $(8.8 \%, 95 \%$ CI 6.8 to 10.7$)$ for rare or occasional wearers $v$ $11.7 \%$ (95\% CI 6.7 to 16.8 ) for those who always wore a hat, $p$ $=0.19)$.

The age and sex specific prevalence rates of the different grades of pterygia are shown in Table 2. A similar increase in prevalence of lesions was seen for all three grades (Table 3). The basal width and the extent from the limbus all increased with increasing grade, but there was no variation by nasal/temporal location or side. Five individuals had three pterygia, two subjects had four lesions, and 45 had bilateral disease.

The presence of pterygium (by individual) was significantly associated with the presence of astigmatism (cylinder $\geqslant-0.5$ dioptre (D), p <0.001). This association increased with increasing grade of lesion ( $p$ for trend $<0.001$ ). The median cylinder for those individuals with pterygium was greater than for those without $(-0.50 \mathrm{D} v-0.25 \mathrm{D}, \mathrm{p}<0.001)$, and increased with higher grades of lesion ( $p$ for trend $<0.001$ ). For eyes with pterygia, the distance a lesion extended from the limbus was greater in those with astigmatism than those without (median $1.25 \mathrm{~mm} v 1.0 \mathrm{~mm}, \mathrm{p}=0.03$ ). The basal width was greater but not significantly so (median $3.6 \mathrm{~mm} \mathrm{v}$ $3.4 \mathrm{~mm}, \mathrm{p}=0.99$ ). The effects of wearing spectacles could not be assessed as only 11 individuals habitually wore distance correction; none of these had pterygia. Similarly, very few individuals ever wore sunglasses.

The visual acuity (VA) of eyes with pterygia was worse than for eyes without pterygia, (median $\log$ MAR acuity $0.1<0.2$, $\mathrm{p}<0.001$ : in the 45 cases of bilateral lesions the eye with the higher grade lesion was considered). The relation between grade of lesion and VA was not significant (median VA for grade 1 lesions $=0.2$, with grade $2=0.2$ and grade $3=0.3, p$

\begin{tabular}{|c|c|c|c|c|}
\hline & Crude OR $(95 \% \mathrm{Cl})$ & $\mathrm{p}$ Value & $\begin{array}{l}\text { Multivariate adjusted OR* } \\
(95 \% \mathrm{CI})\end{array}$ & $\mathrm{p}$ Value \\
\hline Sex & $0.84(0.52$ to 1.37$)$ & 0.37 & $0.65(0.41$ to 1.04$)$ & 0.08 \\
\hline \multicolumn{5}{|l|}{ Age (years) } \\
\hline $21-30$ & 1.00 & & 1.00 & \\
\hline $31-40$ & 2.97 (1.20 to 7.34$)$ & 0.002 & 2.79 (1.17 to 6.89$)$ & 0.003 \\
\hline $41-50$ & 6.58 (1.95 to 22.10$)$ & $<0.001$ & 6.36 (1.89 to 21.39 ) & $<0.001$ \\
\hline 51-and above & 7.02 (2.14 to 23.02$)$ & $<0.001$ & 7.31 (2.36 to 22.70$)$ & $<0.001$ \\
\hline \multicolumn{5}{|c|}{ Outdoor activity 10 years ago } \\
\hline$<5$ hours/day & 1.00 & & 1.00 & \\
\hline$>5$ hours/day & $2.04(1.23$ to 3.40$)$ & 0.001 & $1.64(0.96$ to 2.80$)$ & 0.02 \\
\hline \multicolumn{5}{|l|}{ Smoking } \\
\hline Never smoked & 1.00 & & 1.00 & \\
\hline Ever smoked & $0.96(0.57$ to 1.60$)$ & 0.82 & $0.46(0.24$ to 0.90$)$ & 0.004 \\
\hline
\end{tabular}


$=0.12$ ). Pterygia were significantly larger in eyes with VA worse than 0.3 (mean extent $=1.8 \mathrm{~mm}$ ) compared to those with VA 0.3 or better (mean extent $=1.2 \mathrm{~mm})(\mathrm{p}=0.03)$. However, the difference in basal width was of borderline significance $(p=0.07) ; 3.8 \mathrm{~mm}$ for those with VA worse than $0.3 v 3.2 \mathrm{~mm}$ for VA 0.3 or better). Pterygium was responsible for a reduced visual acuity of 1.0 (6/60 Snellen) or worse in three eyes, of three individuals, and no cases of bilateral blindness.

A multivariate logistic regression model showed that there was a significant increased risk of pterygia with age and outdoor activity 10 years previously but not with sex, controlling for the other factors (Table 4). Smoking was associated with a significantly lower risk in the multivariate model (OR 0.46), although the smoking-pterygia association was not significant in the univariate analysis. The risk of having any pterygium at age 50 years or over was seven times that of a 21-29 year old, whereas extensive time spent outdoors a decade previously conferred a 1.6 times increased risk.

\section{DISCUSSION}

We found a high prevalence rate of pterygium in a provincial, Asian, equatorial population: one in 10 adults over 21 years were affected. Rates increased with age and greater outdoor activity in the past, but there was no significant sex difference. Thicker, opaque ("grade 3") pterygia were larger; both in the extent of encroachment onto the cornea and in basal (limbal) diameter. Pterygium was positively associated with the presence of astigmatism ( $>0.5 \mathrm{D}$ cylinder) and the cylinder was greater for larger, higher grade lesions. This is the first study to assess the Indonesian/Malay racial group, who comprise the majority of the inhabitants of Indonesia, the world's fourth most populous country. It is also the first population based study to assess the association between astigmatism, grade of pterygia, and the extent of the lesion. ${ }^{20}$

Previously reported prevalence rates of pterygia vary widely with race, age, sex, and geography. . $^{3-5} 7811$ 24-26

This may reflect the action of racial (genetic) and/or environmental factors. Black subjects (aged $40-84$ years) in Barbados, which lies in the tropics $13^{\circ}$ north of the equator, had very high rates $(23.4 \%)^{2}$ whereas rates in urban white people (40-101 years) in temperate Melbourne, Australia, were much lower $(1.2 \%){ }^{8}$ Pterygium rates of white people over 40 in temperate rural Australia (6.7\%), ${ }^{8}$ and urban Chinese Singaporeans over $40(6.9 \%)^{5}$ (at the same latitude as our study, one degree north of the equator), were intermediate between these extremes. Our overall rates were lower as the sampling frame included all adults over 21 . However, when a comparable age group is considered - that is, the over 40 year old adults, rates in Sumatra (16.8\%) were higher than all other races previously studied, except the black population of Barbados.

In common with other studies of pterygium, the prevalence of pterygium in Sumatra increased with age. ${ }^{34-1225}$ In contrast with some studies in which pterygia were found to be more common in males, ${ }^{31112}$ but in keeping with some others, ${ }^{2}{ }^{6}$ there was no sex difference in our study. This may reflect variations between study populations in the extent to which there are differences in outdoor activity and sun exposure between the sexes, although direct comparisons of prevalence rates between studies must be made with caution because of potential differences in the definitions, varying age compositions of the study population, measurement techniques, and study methodology.

The pathogenesis of pterygium is associated with p53 oncogene expression, ${ }^{14}{ }^{18}$ fibroblast transformation, ${ }^{15}$ and alterations in cytokines ${ }^{16}$ (for example, TGF- $\beta$ ) and matrix metalloproteinase activity. ${ }^{17}{ }^{19}$ Ultraviolet light exposure has been implicated in p53 mutagenesis ${ }^{18}$ and epidemiologically with the aetiology of pterygium..$^{410-13}$ This agrees with our findings, as ours is a rural population located close to the equator with extensive time spent outdoors. Daytime sun exposure (mean 4.6 hours/day) was greater than both cases (with pterygia, 2.1 hours) and controls (without pterygia, 1.6 hours) in the Singapore case-control study. ${ }^{27}$ Sumatran subjects thus receive high levels of sunlight exposure and hence ultraviolet irradiation. The link is further borne out in our study by the positive relations of pterygia with both past outdoor activity and occupation as graded by sun exposure. This alone may go some way to explaining the high rates in our population. Although we have used a comparatively crude measure of sunlight exposure (self reported time spent outdoors and occupation) as surrogates for ultraviolet exposure there was a definite positive relation after controlling for age, sex, and smoking on multivariate analysis. Racial differences in susceptibility cannot be ruled out, however, and have been described in previous studies. ${ }^{211}$ The low rates of sunglasses wearing, which has been shown to be highly protective against pterygia elsewhere (OR 0.18 ; $95 \%$ CI, 0.06 to $0.59),{ }^{2}$ suggests there is potential for a simple preventative intervention in this population. Health education campaigns advocating sunglasses and reductions in sun exposure, which targeted at-risk groups such as outdoor workers would be beneficial.

The multivariate modelling of risk factors showed an independent increase in risk with age and outdoor activity but conversely a protective effect of smoking (OR 0.46; 95\% CI 0.27 to 0.78 ). This apparent significant effect is puzzling, and persisted despite an extensive exploration of the data for a confounder (such as occupation) that might have accounted for it. A similar finding has also recently been described in the Barbados Eye Survey (OR 0.59; 95\% CI, 0.39 to 0.90 ), with no suggested explanation, and was seen on univariate but not multivariate analysis of the Melbourne Visual Impairment Project. We are not aware of any putative protective mechanism.

It has been shown in clinic based studies that "fleshier," higher grade lesions are more likely to recur after surgery. Our survey found that these higher grade pterygia were associated with a greater extension from the limbus, basal width, and astigmatism. This further validates, in a population based survey, the use of this simple clinical grading system as a predictor of clinical pterygium severity. Clinic studies have shown that pterygia induce a flattening of the corneal curvature and that this may be partially reversed after surgery. ${ }^{28}$ In our survey pterygia were indeed associated with astigmatism and astigmatism was greater for higher grade lesions.

Late surgical treatment of pterygium is associated with more frequent permanent corneal scarring and more complex surgery. Our study suggests that grade ("transparency") is a good indicator of several measures of severity (extent, likelihood of recurrence, induced astigmatism). This would thus support the earlier treatment of higher grade lesions: the inference from these cross sectional data being that fleshier lesions may progress more rapidly, which agrees with clinical impression.

Strengths of this study include the fact that all pterygia were graded and the size assessed by a single trained ophthalmologist and that the population studied is at high risk, being equatorial and with outdoor work common, making the detection of risk factors easier. Although one of the limitations of the study is that nurses performed the initial screen rather than ophthalmologists, we conducted careful training and quality control of the screeners, who were instructed to refer any and all abnormal anterior segment lesions for assessment: over-referral rather than under-referral was encouraged. However, since not all subjects were available for grading by the ophthalmologist, and these were considered as negative for the analysis, the true rates may be even higher than we have described. (Of those 248 examined by the ophthalmologist, 112 had the diagnosis of pterygium confirmed, a rate of 
$45 \%$. If extrapolated to the 49 villagers not rescreened, then an additional 22 individuals who might have had pterygia were not considered in the analysis. This would give a higher crude overall (not age adjusted) rate of $11.1 \%$ rather than the crude rate of $9.3 \%$ that we report. Further limitations are that this is also a cross sectional study in which both ocular prevalence data and risk factor information were derived concurrently, rather than a case-control or cohort study, and that ultraviolet light exposure was necessarily derived from questionnaire and occupational data rather than objective measurement.

Our study in provincial, equatorial Indonesia found one of the highest rates of pterygia in the world and determined a potentially modifiable risk factor: outdoor activity. This is the first population based study to demonstrate the validity of the clinical grading scheme based on the opacity of pterygia and the largest survey to assess pterygia in indigenous South East Asians.

\section{ACKNOWLEDGEMENTS}

Grant support: Singapore Eye Research Institute for National Medical Research Council (NMRC), SERI/MG/97-04/0005, Singapore and (Dr Saw) R209/01/2001-PG SERI \& NMRC/SERI/MG/97-04/0005.

We would like to thank the staff of PT Riau Andalan Pulp and Paper especially Fauzan Chalid, and Yayasan Putra Bangsa, Indonesia. We would also like to express special thanks to the Indonesia health survey team (team leaders Nimit Nico and Juwendi Jamal) and especially the "myopia team," Anwar, Zakaria, Darneli, and Said.

\section{Authors' affiliations}

G Gazzard, Singapore National Eye Centre, 11 Third Hospital Avenue, Singapore 139651, Singapore Eye Research Institute, Republic of Singapore, and the Institute of Ophthalmology, Bath Street, London ECIV 9EL, UK

S-M Saw, Department of Community, Occupational and Family Medicine, National University of Singapore and The Singapore Eye Research Institute, Republic of Singapore

M Farook, Singapore National Eye Centre, 11 Third Hospital Avenue, Singapore 139651, Republic of Singapore

D Koh, S-E Chia, C-Y Hong, Department of Community, Occupational and Family Medicine, National University of Singapore, 16 Medical Drive, Singapore 117597, Republic of Singapore

D Widjaja, PT Riau Andalan Pulp and Paper, Kerinci, Indonesia

D T H Tan, The Singapore Eye Research Institute; Singapore National Eye Centre, 11 Third Hospital Avenue and Department of

Ophthalmology, National University of Singapore, Singapore 117597,

Republic of Singapore, and the Institute of Ophthalmology, Bath Street, London ECIV 9EL, UK

\section{REFERENCES}

1 Solomon A, Pires RT, Tseng SC. Amniotic membrane transplantation after extensive removal of primary and recurrent pterygia. Ophthalmology 2001;108:449-60.

2 Luthra R, Nemesure B, Wu S-Y, et al. Frequency and risk factors for pterygium in the Barbados Eye Study. Arch Ophthalmol $2001 ; 119: 1827-32$
3 Panchapakesan J, Hourihan F, Mitchell P. Prevalence of pterygium and pinguecula: the Blue Mountains Eye Study. Aust NZ J Ophthalmol 1998;26(Suppl 1):S2-5.

4 Saw SM, Tan D. Pterygium: prevalence, demography and risk factors. Ophthalmic Epidemiol 1999;6:219-28.

5 Wong TY, Foster PJ, Johnson GJ, et al. The prevalence and risk factors for pterygium in an adult Chinese population in Singapore: the Tanjong Pagar survey. Am J Ophthalmol 2001;131:176-83.

6 Forsius H, Maertens K, Fellman J. Changes of the eye caused by the climate in Rwanda, Africa. Ophthalmic Epidemiol 1995;2:107-13.

7 Rojas JR, Malaga H. Pterygium in Lima, Peru. Ann Ophthalmol 1986;18:147-9.

8 McCarty CA, Fu CL, Taylor HR. Epidemiology of pterygium in Victoria, Australia. Br J Ophthalmol 2000;84:289-92.

9 Saw SM, Banerjee K, Tan D. Risk factors for the development of pterygium in Singapore: a hospital-based case-control study. Acta Ophthalmol Scand 2000;78:216-20.

10 Hill JC, Maske R. Pathogenesis of pterygium. Eye 1989;3:218-26.

11 Moran DJ, Hollows FC. Pterygium and ultraviolet radiation: a positive correlation. Br J Ophthalmol 1984;68:343-6.

12 Coroneo MT. Pterygium as an early indicator of ultraviolet insolation: a hypothesis. Br J Ophthalmol 1993;77:734-9.

13 Spierer A, Rosner M, Belkin M. Pterygium, solar ultraviolet radiation and myopia. Metab Pediatr Syst Ophthalmol 1985;8:47-8.

14 Tan DT, Lim AS, Goh HS, et al. Abnormal expression of the p53 tumor suppressor gene in the conjunctiva of patients with pterygium. Am J Ophthalmol 1997;123:404-5

15 Chen JK, Tsai RJ, Lin SS. Fibroblasts isolated from human pterygia exhibit transformed cell characteristics. In Vitro Cell Devel Bio 1994;(Animal 30A):243-8.

16 Kria L, Ohira A, Amemiya T. Immunohistochemical localization of basic fibroblast growth factor, platelet derived growth factor, transforming growth factor-beta and tumor necrosis factor-alpha in the pterygium. Acta Histochem 1996;98:195-201.

17 Dushku N, John MK, Schultz GS, et al. Pterygia pathogenesis: corneal invasion by matrix metalloproteinase expressing altered limbal epithelia basal cells. Arch. Ophthalmol 2001;119:695-706.

18 Dushku N, Reid TW. P53 expression in altered limbal basal cells of pingueculae, pterygia, and limbal tumors. Curr Eye Res 1997; 16:1179-92.

19 Li DQ, Lee SB, Gunja-Smith Z, et al. Over-expression of collagenase (MMP-1) and stromelysin (MMP-3) by pterygium head fibroblasts. Arch Ophthalmol 2001;119:71-80.

20 Tan DH, Chee SP, Dear KBG, et al. Effect of pterygium morphology on pterygium recurrence in a controlled trial comparing conjunctival autografting with bare sclera excision. Arch Ophthalmol 1997; 115:1235-40.

$21 \mathrm{Ti}$ SE, Chee SP, Dear KB, et al. Analysis of variation in success rates in conjunctival autografting for primary and recurrent pterygium. $\mathrm{Br} J$ Ophthalmol 2000;84:385-9.

22 Wesemann W, Dick B. Accuracy and accommodation capability of a handheld autorefractor. J Cataract Refract Surg 2000;26:62-70.

23 Goss DA, Grosvenor T. Reliability of refraction-a literature review. J Am Optom Assoc 1996:67:619-30.

24 Ashaye AO. Pterygium in lbadan. West Afr J Med 1991;10:232-43.

25 Norn MS. Prevalence of pinguecula in Greenland and in Copenhagen, and its relation to pterygium and spheroid degeneration. Acta Ophthalmol 1979:57:96-105.

26 Norn MS. Spheroid degeneration, pinguecula, and pterygium among Arabs in the Red Sea territory, Jordan. Acta Ophthalmol 1982;60:949-54.

27 Khoo J, Saw SM, Banerjee K, et al. Outdoor work and the risk of pterygia: a case-control study. Int Ophthalmol 1998;22:293-8.

28 Fong KS, Balakrishnan V, Chee SP, et al. Refractive change following pterygium surgery. CLAO J 1998;24:115-7. 